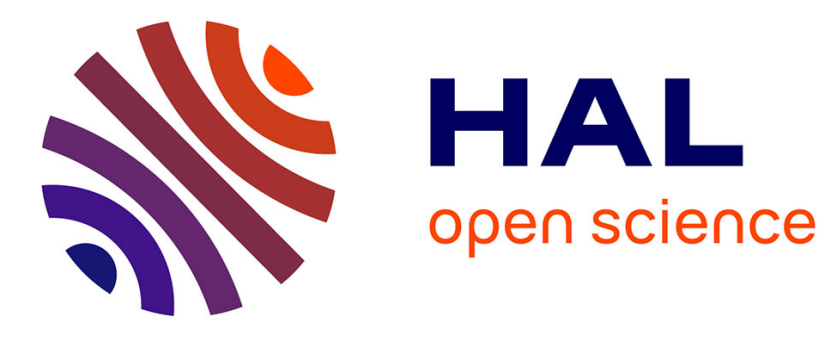

\title{
The Grimm-Verner Push Chain and Contrast Preservation Theory.
}

Roland Noske

\section{To cite this version:}

Roland Noske. The Grimm-Verner Push Chain and Contrast Preservation Theory.. Botma, Bert \& Noske, Roland. Phonological Explorations. Empirical, Theoretical and Diachronic Issues, 548, De Gruyter, X, 355 p., 2012, Linguistische Arbeiten, 978-3-11-029516-0, e-ISBN: 978-3-11-029517-7. hal-01191430

\section{HAL Id: hal-01191430 https://hal.univ-lille.fr/hal-01191430}

Submitted on 1 Sep 2015

HAL is a multi-disciplinary open access archive for the deposit and dissemination of scientific research documents, whether they are published or not. The documents may come from teaching and research institutions in France or abroad, or from public or private research centers.
L'archive ouverte pluridisciplinaire HAL, est destinée au dépôt et à la diffusion de documents scientifiques de niveau recherche, publiés ou non, émanant des établissements d'enseignement et de recherche français ou étrangers, des laboratoires publics ou privés. 


\title{
Roland Noske
}

\section{The Grimm-Verner Push Chain and Contrast Preservation Theory*}

\author{
1 Introduction
}

Traditional textbooks from before the 1980s treat Grimm's Law and Verner's Law as essentially four different historical changes (i.e. three separate changes known as the three 'acts' of Grimm's Law, and Verner's Law). In these descriptions not much attention, if any, is given to the idea that the changes are systematically linked. Nevertheless, the idea of a systematic link, at least for the three parts of Grimm's Law, was advanced by Grimm himself in his Geschichte der deutschen Sprache, where he writes (1848: 393):

One can appropriately compare the Sound Shift with vehicles that move in a circle: as soon as a wheel arrives at the place of the preceding one, then its own place has already been taken by a following wheel, but no wheel will overtake another one. In their movement there cannot remain space anywhere that is not immediately filled. [My translation, R.N. $]^{1}$

Grimm describes here something what we would now call a chain shift. From the above cited passage, it cannot be concluded whether Grimm saw the three changes as a push or a pull chain.

In the period after the publication of these words, the Neogrammarian doctrine became prevalent. This doctrine states that every sound change should be phonetically motivated, or be caused by analogy. Such a stance is incompatible with the idea of a chain shift, where a part of the shift is due to systemic pressure, caused by the need to maintain contrast. The

* I would like to thank Joaquim Brandão de Carvalho, Olga Fischer, Piotr Gąsiorowski, Janet Grijzenhout, Martin-Joachim Kümmel, Jean-Pierre Montreuil, Cédric Patin, Christopher Piñón, Norval Smith and Janet Watson for valuable discussions and suggestions. I also wish to thank two anonymous reviewers for their useful comments. Remaining errors are mine. The analysis presented in this paper was presented in various stages of development to audiences in Amsterdam, Lille, Nantes, Orléans, Gniezno and Manchester.

1 "Man mag die lautverschiebung passend wagen vergleichen, die in einem kreise umlaufen: sobald ein rad die stelle des vorangehenden erreicht ist seine eigne bereits von einem folgenden eingenommen, aber keins ereilt das andere, bei ihrer bewegung kann nirgend raum bleiben, der nicht alsbald ausgefüllt würde." 
Neogrammarian stance must be the explanation why this passage in Grimm (1848) did not receive any attention in the late 19th century.

It took a long time for the idea of Grimm's Law as a chain shift to reemerge. Eighty-four years later, Kretschmer (1932: 274) describes Grimm's Law clearly as a push chain:

Hence, the process was the following: when the aspirated voiced stop approached the plain voiced stop and threatened to coincide with it, speakers made an effort to differentiate the plain voiced stop from it: the realization of this phoneme then led to a fortis articulation. But as soon as the plain voiced stop came close to the former voiceless stop, the latter also changed in order to avoid a merger, such that it was aspirated and finally became spirantized. [My translation, R.N.]

Kretschmer's insight is repeated by Luick (1940: 802-803). Later, Kiparsky (1971) analyzes Grimm's Law as a pull chain using the SPE (Chomsky \& Halle 1968) framework. Also Fox (1976), Bynon (1977) and Campbell $\left(1994,{ }^{2} 2004\right)$ see Grimm's Law as a chain shift.

In this article, I will show that Verner's Law must have been part and parcel of the same chain shift. For this I will make use of an independently needed modification of the traditionally assumed Proto-Indo-European (PIE) obstruent inventory. I will then show how the Grimm-Verner Push Chain can be expressed formally in modern phonological theory. But first, I will give an overview of the traditional view.

\section{An outline of the traditional view}

\subsection{The Proto-Indo-European obstruent system}

The Neogrammarian view on the PIE obstruent inventory as put forth by Brugmann \& Delbrück $\left(1886,{ }^{2} 1897\right)$ and modified in later research involves a series of 12 stops and a single fricative, cf. the overview in (1) (tenues, mediae and mediae aspiratae are the traditional Neogrammarian terms for voiceless, voiced and breathy voiced stops respectively):

2 "Der Vorgang war also folgender: als die Media aspirata sich der Media annäherte und mit ihr zusammenfallen drohte, bemühten sich die Sprechenden die Media von ihr zu differenzieren; die Realisation dieses Phonems führte dabei zur fortisArtikulation. Sobald aber die Media dadurch der alten Tenuis nahkam, wurde diese auch differenziert, um den Zusammenfall zu vermeiden und zwar aspiriert und schließlich spirantisiert." 
(1) PIE obstruent inventory, traditional view ${ }^{3}$

\begin{tabular}{lcccc}
\hline & $\begin{array}{l}\text { voiceless } \\
\text { stops } \\
\text { (tenues) }\end{array}$ & $\begin{array}{l}\text { voiced } \\
\text { stops } \\
\text { (mediae) }\end{array}$ & $\begin{array}{l}\text { breathy voiced ('voiced } \\
\text { aspirated') } \\
\text { aspiratae) }\end{array}$ & fricative \\
\hline labial & $\mathrm{p}$ & $\mathrm{b}$ & $\mathrm{b}^{\mathrm{h}}$ & \\
dental & $\mathrm{t}$ & $\mathrm{d}$ & $\mathrm{d}^{\mathrm{h}}$ & $\mathrm{s}$ \\
velar & $\mathrm{k}$ & $\mathrm{g}$ & $\mathrm{g}^{\mathrm{h}}$ & \\
labiovelar & $\mathrm{k}^{\mathrm{w}}$ & $\mathrm{g}^{\mathrm{w}}$ & $\mathrm{g}^{\mathrm{wh}}$ & \\
\hline
\end{tabular}

We can thus represent the PIE obstruent system in the following simplified diagram (where the uppercase characters generalize over the places of articulation):

(2) PIE obstruent system: T D D (in four places of articulation), $s$

\subsection{The Proto-Germanic accent shift}

In Proto-Germanic, there was an accent shift from the free, lexically determined stress system (as still found in, e.g., Russian) to a word or root initial stress. According to several authors adhering to the traditional view (e.g., Lehmann 1961: 69) this would have conditioned the Germanic sound shift (Grimm's Law, see section 2.3, below). An example of correspondences with other IE languages is given in (3), where Gothic and Old English (OE) represent PG in the relevant aspects:

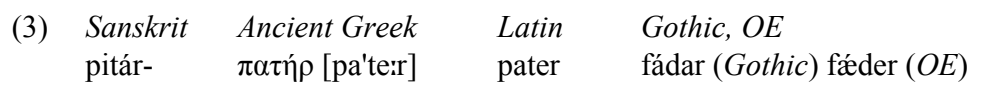

\subsection{Grimm's Law}

Grimm's Law consists of three 'acts': voiceless stops spirantize (act 1); breathy voiced stops become fricatives (act 2) and voiced stops become voiceless (act 3):

3 I give here the traditional view as given by Lehmann (1952). It was later shown that one of these, the palatal stop series, can be regarded as allophonic (although this remains a matter of debate). Brugmann \& Delbrück further assumed that the PIE inventory also contained a series of voiceless aspirates in addition to a voiced series. This idea was abandoned in subsequent research. 
(4) Grimm's Law (Rask 1818, Grimm 1822 and later amendments)
a. (act 1)
$\mathrm{p}>\mathrm{f}$
$\mathrm{t}>\theta$
$\mathrm{k}>\mathrm{x}(>\mathrm{h})$
$\mathrm{k}^{\mathrm{w}}>\mathrm{x}^{\mathrm{w}}\left(>\mathrm{h}^{\mathrm{w}}\right)$
b. (act 2)
$\mathrm{b}^{\mathrm{h}}>* \beta(>\mathrm{b})$
$\mathrm{d}^{\mathrm{h}}>*$ * $(>\mathrm{d})$
$\mathrm{g}^{\mathrm{h}}>*_{\mathrm{f}}(>\mathrm{g})$
c. $($ act 3$)$
$\mathrm{d}>\mathrm{t}$
$\mathrm{g}>\mathrm{k}$
$\mathrm{g}^{\mathrm{w}}>\mathrm{k}^{\mathrm{w}}$

As one can see, act 2 leads to an unattested voiced fricative that is subsequently changed into a stop by a supposed occlusivization process. I will come back to this process below, in section 3.3. Grimm's Law can be represented schematically as in (5):

(5) Diagram of Grimm's Law
a. (act 1)
b. (act 2)
Pre-PG
PG1 PG2
c. (act 3 )

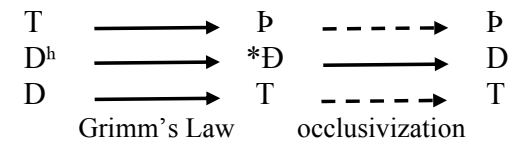

Examples of the workings of the law can be shown by the correspondences between PIE and English (and Dutch for one example) in (6). ${ }^{4}$
(6) a. (act 1) *ped $>$ foot
*trei $>$ three
*kāat- $>$ hate
b. (act 2) * $\underline{b}^{\mathrm{h}}$ rátēer $>\underline{\text { brother }} *^{\mathrm{d}^{\mathrm{h}}}$ ugater $>$ daughter $* \underline{g}^{\mathrm{h}}$ aidos $>$ goat $* \mathrm{~g}^{\text {wh }}$ ermos $>$ warm
c. (act 3$) * \underline{\text { bend }}>$ pen $\quad *$ dekm $>$ ten ${ }^{*} \mathrm{~g}^{\mathrm{w}} \mathrm{a}->$ come; $>$ kwam $($ preterit, Dutch)
*gelə- > cold

\subsection{Verner's Law}

Lottner (1862) lists a number of types of counter-examples to Grimm's Law. The most important class is that of voiced stop reflexes of voiceless stops, where one would expect voiceless fricatives. Examples are given in (7). ${ }^{5}$

${ }^{4}$ In these examples, we see some additional changes in the evolution from PG to English: $h$ in hate is the result of change from the velar to the glottal fricative, which took place after spirantization (hence $k>x>h$ ). In act 2, in addition to the $\mathrm{PIE}>\mathrm{PG}$ loss of aspiration, the PIE labiovelar aspirated stop lost its plosive character and became a glide, and in act 3 , in addition to being devoiced, the labiovelar lost its labial character to become plainly velar. The labial character was maintained in the Dutch preterit form kwam 'came-SG'.

5 In these examples, thorn $(b)$ represents [ $\theta$ ] (but intervocalically [ð], see note 7). The consonantal alternations in the verb paradigms in (7) are traditionally referred to as grammatischer Wechsel 'grammatical alternation'. 
(7) a. Original *p (no examples of the alternation in the modern languages) $O E$ hebban - hōf hōfon hafen ('lift' $c f$. heave)

b. Original *t (the alternation survives in modern German) $O E$ cwepan (cwipp) cwæp - cwǣdon cweden ('say': cf. quoth) $O E$ sēopan (sīepp) sēap - sudon soden ('boil' $c f$. seethe) Modern German schneiden - schnitt geschnitten ('cut')

c. Original *k (survives in modern German and Dutch) Modern German ziehen ziehe - zog gezogen ('pull') $O E$ pēon (pīehp) pēah - pigon pigen ('prosper' cf. Modern Germ. gedeihen) Modern Dutch zien zie gezien - zag zagen ('see', Dutch lost intervocalic h) Modern Dutch slaan sla - sloeg sloegen geslagen ('beat')

Verner (1876) analyzes these alternations as being related to alternations of the position of the original PIE accent. His law states (1876: 114):

IE $k, t, p$ first shifted to $h, p, f$ in all environments; the voiceless fricatives thus originating, together with the voiceless fricative $s$ inherited from Indo-European, then became voiced medially in voiced environments, but remained voiceless when they were the final sounds of accented syllables. [Translation by Lehmann $1967]^{6}$

Verner uses here the expression 'final sounds of accented syllables' because he believes that intervocalic consonants belong to the former syllable (Verner 1876: 117; I will briefly come back to this assumption below in footnote 23). The effect of the law can be illustrated by the forms in (8):

\begin{tabular}{|c|c|c|c|c|}
\hline $\begin{array}{l}\text { (8) Proto-Indo- } \\
\text { European } \\
\text { (reconstructed) }\end{array}$ & Sanskrit & Ancient Greek & $\begin{array}{l}\text { Gothic, } \\
\text { Old English } \\
(O E)\end{array}$ & $\begin{array}{l}\text { Modern } \\
\text { High } \\
\text { German }\end{array}$ \\
\hline *b $\mathrm{b}^{\mathrm{h}}$ rátēr & $\mathrm{b}^{\mathrm{h}}$ rătar- & $\begin{array}{l}\varphi \rho \bar{\alpha} \tau \eta \rho \\
\left(\left[p^{\mathrm{h}} \text { ra:te:r] }\right)\right.\end{array}$ & $\begin{array}{l}\text { brōpar (Gothic) } \\
\text { brōpor }(O E)\end{array}$ & Bruder \\
\hline *potér & pitár- & $\begin{array}{l}\pi \alpha \tau \eta^{\prime} \rho \\
\text { ([pa'te:r] })\end{array}$ & $\begin{array}{l}\text { fadar (Gothic) } \\
\text { fæder }(O E)\end{array}$ & Vater \\
\hline
\end{tabular}

In the word for 'brother', $t$ in PIE, Sanskrit and Ancient Greek corresponds to $b$ in Gothic (where it represents $[\theta]$ ) and OE (where it represents [ð] $)^{7}$ according to act 1 (spirantization) of Grimm's Law. Verner's Law does not

6 "Indogerm. $k, t, p$ gingen erst überall in $h, p, f$ über; die so entstandenen tonlosen fricativae nebst der vom indogermanischen ererbten tonlosen fricativa $s$ wurden weiter inlautend bei tönender nachbarschaft selbst tonend, erhielten sich aber als tonlose im nachlaute betonter silben."

7 In intervocalic position, $p$ in OE represents [ð]. The voiced character is the result of a voicing process that took place only in the early stages of Old English, and that was independent from Verner's Law (Campbell 1959: 179-180). 
apply here, because the preceding vowel is stressed. By contrast, in the word for 'father', PIE, Sanskrit and Ancient Greek $t$ corresponds not to $\theta$, but to $d$. In most modern Germanic languages, like Dutch, English and Icelandic, this contrast has levelled out, but it remained in High German, despite additional shifts.

As Verner mentions in his own description of the law, cited above, the law applies only medially. However, many scholars, like Jespersen (1933: 230), assume that the law applies also word-finally. I will come back to this below.

The functioning of Grimm's Law and Verner's Law combined is shown in the diagram in (9):

(9) Diagram of Grimm's Law and Verner's Law

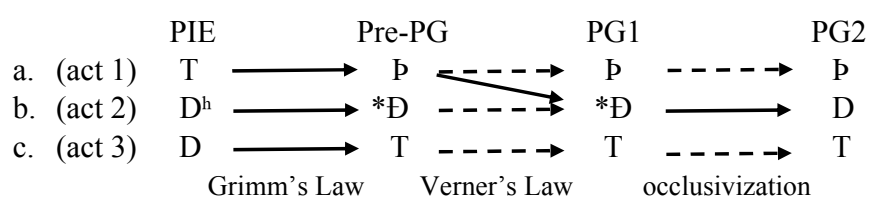

Verner mentions that he cannot derive $D$ at PG2 directly from $T$, "for this would be a sound innovation directly counter to the main direction of the sound shift [i.e., act 3 of Grimm's Law, $D>T$, RN], which produced a voiceless stop from the Indo-European voiced stop" (1876: 101, translation by Lehmann 1967, italics mine) ${ }^{8}$ It is for this reason that he has to assume that his law applies after that of Grimm, and that occlusivization applied across the board.

\section{Problems related to the traditional view}

The traditional view of the PIE obstruent system and the PG sound changes has given rise to a number of problems. They concern (i) the typology of the PIE obstruent system, (ii) the alleged occlusivization process, (iii) the fact that the changes are not non-monotonic, (iv) the fact that $s$ does not undergo occlusivization and (v) the number of changes Germanic must have

\footnotetext{
8 "Dagegen kann man die germanische tönende explosiva nicht auf directem wege durch mittönen der stimme aus der indogermanischen explosiva entstanden sein, denn dies würde ein lautübergang sein, der gerade gegen die hauptrichtung der lautverschiebung die aus der indogermanischen tönenden explosiva tonlose explosiva hervorbrachte, gehen würde."
} 
undergone vis-à-vis PIE, compared to the classical languages like Sanskrit and Greek. I will briefly treat each of these problems.

\subsection{The typological improbability of the traditional obstruent inventory}

The first problem concerns the typological improbability of the alleged PIE obstruent inventory. As mentioned by several authors (e.g., Pedersen 1951; Martinet 1955; Jakobson 1958), the occurrence of mediae aspiratae, i.e. voiced aspirates (in fact breathy voiced or "murmured" stops), without voiceless aspirated stops is typologically very strange. ${ }^{9}$ To make matters worse, there are also problems regarding the fact that the occurrence of $b$ is rare in PIE, and that there is an apparent constraint against the combination: voiced stop-vowel-voiced stop (the so-called * deg constraint) in PIE. Under the traditional model these facts remain unexplained. For more details on these points, see Salmons (1993: 16-18).

\subsection{The alleged occlusivization process}

A second problem concerns Verner's Law and the invoked occlusivization process. Here one important problem is that the intermediate stage of voiced fricatives, which should have resulted after the application of Verner's Law and before occlusivization, has not been unambiguously attested. It is true that certain PIE voiceless stops occur as voiced fricatives in historical data. However, it is more straightforward to derive these from voiced stops than vice versa because occlusivization is much less common than spirantization. On top of that, there are several indications that the examples of the original mediae aspiratae (voiced aspirates) which indeed show up as voiced fricatives in historical records, probably have gone through a stage where they were voiced stops (Luick 1940: 800-801).

\subsection{The absence of monotonicity}

As mentioned above, Verner cannot derive $\mathrm{D}$ directly from $\mathrm{T}$ as this would go against the 'main direction' $\mathrm{D}>\mathrm{T}$ (Grimm's Law, act 3). Therefore, he has to assume the complicated derivation $\mathrm{T}>\mathrm{P}>\mathrm{D}>\mathrm{D}$ (Grimm's Law, act 1, followed by Verner's Law and occlusivization). However, on closer

9 Kelabit, a language of Northern Borneo, is reported as an exception by Blust (1974, 2006). 
inspection we see that this also goes against a main direction: first there is a spirantization $\mathrm{T}>\mathrm{P}$, and then, after application of Verner's Law, exactly the opposite development, i.e. a despirantization (or: occlusivization) in the change $\mathrm{Ð}>\mathrm{D}$. Hence, we have a change $[-$ cont $]>[+$ cont $]>[-$ cont $]$. This is likewise true for act 2 of Grimm's Law, which is followed by occlusivization $\left(\mathrm{D}^{\mathrm{h}}>\mathrm{D}>\mathrm{D}\right)$. In both cases, the change is not monotonic because there is a reversal of an earlier change. So, under this scenario too, there are developments against a 'main direction'. In generative terms, because these changes are not monotonic, they are of the so-called Duke of York Gambit ${ }^{10}$ type, which suggests the possibility of a faulty analysis (see Pullum 1976). ${ }^{11}$

\subsection{The absence of occlusivization concerning $s$}

There is yet another problem connected to occlusivization: precisely the only attested fricative, i.e. $s$ in PIE, which changed to $z$ in PG after a non-stressed vowel by Verner's Law, did not undergo the alleged occlusivization. This casts further doubt on the assumption that occlusivization took place at all. To my knowledge, this problem regarding the traditional view has hitherto gone unnoticed.

3.5 The position of Proto-Germanic and Sanskrit compared to Proto-IndoEuropean

Under the traditional view, the 'classical languages' (especially Sanskrit) seem close to PIE but Germanic seems to have undergone substantial sound changes in the transition from PIE. In their focus on and admiration of Sanskrit and other classical languages, the Neogrammarians gave no attention to the logical possibility that it is Sanskrit that has undergone substantial changes compared to PIE.

\footnotetext{
10 "The Grand Old Duke of York / He had ten thousand men / He marched them up a great high hill / And he marched them down again."

${ }^{11}$ The lack of monotonicity Verner's scenario was first noticed by F.L. Wells (19031905: 523) who stated: “[t]he chronological relation of Verner's law to Grimm's law is not to be dismissed so lightly as Verner himself dismissed it. It will not suffice to accept unquestioningly Verner's dictum that voicing must have occurred after spirantization, since $f-v$ [specified as bilabial in a footnote, R.N.] is quite as much against the Hauptrichtung [main direction, R.N.] - if it has any - as $p-b$ or $p h-$ bh."
} 


\section{Glottalic Theory and its consequences for Verner's Law}

Due to the typological improbability of the classic view on the PIE obstruent inventory (as mentioned in the previous section), this view has come increasingly under attack. Emonds (1972), Hopper (1973, 1997a, b, 1982), Gamkredlidze \& Ivanov (1973, 1995), Haudricourt (1975), Vennemann (1984), Kortlandt (1985, 1988) and Haider (1985) have all produced alternatives to the classic inventory, whereby, with the exceptions of Emonds and Haider, the voiced stops were replaced by voiceless glottalized stops (ejectives). ${ }^{12}$ These models are subsumed under the name of 'Glottalic Theory'. For ease of exposition I give here Hopper's (1973, 1997a, 1997b, 1982) model, but the point made here also holds for the other models of the Glottalic Theory, and mutatis mutandis, for Emonds' and Haider's models. ${ }^{13}$

(10) Hopper's $(1973,1997 \mathrm{a}, \mathrm{b}, 1982)$ glottalic model compared to the traditional model (Lehmann 1952)

$\begin{array}{llll} & \text { Series I } & \text { Series II } & \text { Series III } \\ \begin{array}{l}\text { Traditional model } \\ \text { (Lehmann 1952) }\end{array} & \mathrm{b}, \mathrm{d}, \mathrm{g} & \mathrm{b}^{\mathrm{h}}, \mathrm{d}^{\mathrm{h}}, \mathrm{g}^{\mathrm{h}} & \mathrm{p}, \mathrm{t}, \mathrm{k} \\ \begin{array}{l}\text { Glottalic model (Hopper } \\ \text { 1973, 1997a, b, 1982) }\end{array} & \mathrm{p}^{\prime}, \mathrm{t}^{\prime}, \mathrm{k}, & \mathrm{b}, \mathrm{d}, \mathrm{g} & \mathrm{p}, \mathrm{t}, \mathrm{k}\end{array}$

With this model, the typological problems concerning the obstruent inventory have been resolved: there are no longer voiced aspirates, the rarity of the occurrence of $b$ (which is $p$ ' under the glottalic model) is in accordance with typological observations (labials are often absent in ejective series), and the glottalic equivalent to the $* d e g$ constraint (now: *ejective-vowel-ejective) is typologically straightforward. ${ }^{14}$

${ }^{12}$ Emonds (1972) replaces the voiced stops of the traditional model by plain voiceless ones and the plain voiceless stops by aspirated voiceless ones. Haider (1985: 11ff) replaces the voiced stops by implosives (or, rather, "nonexplosives". The 'implosive' version of the theory copes with a number of objections that have been raised against Glottalic Theory. For further discussion, see Kümmel (2012).

${ }^{13}$ For an overview of the different models within the Glottalic Theory see Salmons (1993: 31) and Vennemann (2006: 130).

${ }^{14}$ A general criticism of the Glottalic Theory is is that it makes the analysis of Germanic and some other branches of IE simpler, but that of other branches more complicated. In this paper I cannot go into the complexities of this discussion, but I refer the reader to Salmons (1993) for arguments in favour of the Glottalic Theory and to Job (1995) for arguments against it. A broad spectrum of discussions of the Glottalic Theory by various researchers can be found in Vennemann (ed., 1989). 
This model has important consequences for Verner's Law. As noted by Vennemann (1984: 20-22, 1985: 533-535), Verner's Law can now be assumed to have taken place before the spirantization part of Grimm's Law, and so it simply changes voiceless plain obstruents into voiced ones, i.e. mostly voiceless plain stops into voiced plain stops, but also $s$ to $z$. This is so because the change T $>$ D does not go anymore against the 'main direction' (see section 2.4), i.e. act 3 of Grimm's Law, which has now become $T^{\prime}>T$. This assumption, which has been endorsed by Kortlandt (1985), solves three major problems mentioned in section 3: that of the relative chronology of the laws of Grimm and Verner, that of the non-monotonicity of the shifts, as well as that of the non-application of occlusivization to $s$. Fourthly, it can now be assumed that a spirantization process has applied to certain voiced stops, rather than that a less likely occlusivation process applied to voiced fricatives. Thus, the diagram of the Germanic sound changes in (9) can now be modified and simplified:

(11) Diagram of Grimm's Law and Verner's Law under the Glottalic Theory and the relative ordering proposed by Vennemann (1984)

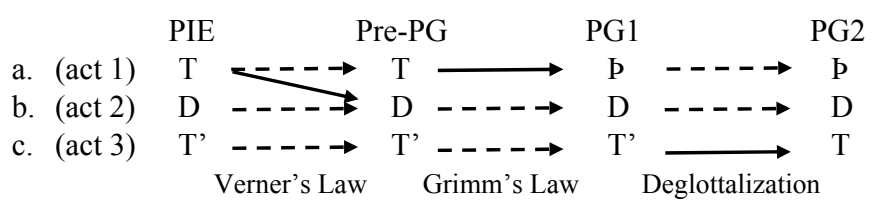

Concerning Grimm's Law, it can be concluded that act 2 (which was $D^{h}>\oslash$ $>D$ ) has disappeared, because PIE $D^{h}$ has been replaced by $D$, so there is no change $(D$ remains $D)$. Concerning act 3 , we see that PIE $D$ has been replaced by a glottalized stop, $T$, , so act 3 now represents a deglottalization process instead of a devoicing process. From now on, we will refer to act 1 of the now less complex Grimm's Law as 'Germanic Spirantization, and to act 3 as '(Germanic) Deglottalization'.

\section{The laws of Verner and Grimm from a synchronic perspective}

As we have just seen, there are many advantages to the Glottalic Theory and the chronological ordering of Verner's Law before Grimm's Law. As we

Kümmel (2007: 47-54 \& 189-192) shows that it is difficult to find typological parallels to a change from glottalized stops to plain stops, which the Glottalic Theory has to assume for nearly all branches. 
have seen, the assumption of the new ordering is motivated by the problems that arise if one assumes the reverse ordering. There is no principled reason, however, not to assume that both processes applied at the same time. If we make this assumption, and if we formalize the two processes as synchronic phonological rules, then a very interesting picture emerges. (12) and (13) are rules in the model of Chomsky and Halle (1968) (henceforth SPE) representing Verner's Law and act 1 of Grimm's Law (Germanic Spirantization) respectively: ${ }^{15}$

(12) Verner's Law ${ }^{16}$

$$
\left[\begin{array}{l}
\text { - voice } \\
\text { - constr.gl. }
\end{array}\right] \rightarrow[+ \text { voice }] /\left[\begin{array}{c}
\mathrm{V} \\
\text { - stress }
\end{array}\right]([+ \text { voice }]) \_ \text {V }
$$

(13) Grimm's Law, act 1: Germanic Spirantization

$$
\left[\begin{array}{l}
- \text { voice } \\
- \text { constr.gl. }
\end{array}\right] \rightarrow[+ \text { cont }] \quad(\text { no context })^{17}
$$

The feature [-constricted glottis] is used here to restrict the class of undergoers of the shifts to voiceless plain stops, thus excluding glottalized stops. This means, therefore, that Germanic Spirantization is in an Elsewhere relationship with Verner's Law; that is, the context of Verner's Law is properly included in that of Germanic Spirantization. Hence, the order of application (i) Verner's Law, (ii) Germanic Spirantization follows automatically from Kiparsky's $(1973,1982)$ Elsewhere Condition (or from the principle of Proper Inclusion Precedence proposed by Koutsoudas, Sanders and Noll (1974)): According to these principles, Verner's Law has precedence over Germanic Spirantization because its domain of application is more specific.

\footnotetext{
${ }^{15}$ As noted by an anonymous reviewer, the features [voice] and [constricted glottis] are nowadays mostly considered to be monovalent. Hence, in modern frameworks, it is not possible to refer to negative specifications of these features like I do in the SPE-style rules in (12 and (13). This matter, however, is immaterial to the present demonstration of the elsewhere relationship between the rules.

${ }^{16}$ The specification ([+ voice]) must be part of the rule in (12) because Verner's Law also applied after a non-stressed vowel followed by a voiced consonant, cf. the PG past participle *wurd- 'turned' (which is followed by a stressed ending), where $d$ results from the application of Verner's law).

${ }^{17} \mathrm{I}$ abstract away from the fact that spirantization does not apply to the stop in question if a stop is preceded by $s$ or if it is the second member of a cluster of stops. This is of no consequence for the matter discussed here (but see section 7.4.4, below).
} 
In this experiment of regarding Germanic Spirantization and Verner's Law as part of a synchronic phonological system, the Elsewhere relationship between the structural descriptions of the Germanic Spirantization and Verner's Law reveals that these laws must be somehow related: it is striking that these two most famous Germanic sound laws have exactly the same undergoer, i.e. a voiceless plain obstruent, and that their order of application can be determined by a general principle. It is therefore tempting to investigate the hypothesis that the Germanic Spirantization and Verner's Law were in fact part of a single process, or were triggered by the same phenomenon. I will do this in the next section.

\section{Grimm's Law and Verner's Law as a single bifurcating push chain}

I now come to the central hypothesis of this article. In section 4 it was shown that with the adoption of Glottalic Theory, act 2 of Grimm's Law is eliminated. Grimm's Law then consists of only two processes, i.e. (i) contextsensitive spirantization of voiceless stops and (ii) deglottalization of glottalized stops. Verner's Law now simply involves voicing of voiceless stops in contexts in which spirantization did not apply.

This scenario, together with the elsewhere relationship between Grimm's Law and Verner's Law that we established in the previous section, suggests that the laws were part of a single, bifurcating chain shift:

(14) The Grimm-Verner chain shift

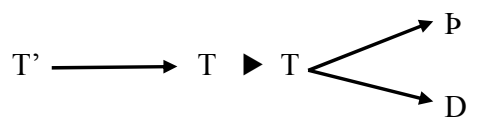

Ejectives deglottalized to voiceless full stops. Because of this, and in order to maintain contrast, original voiceless full stops were pushed to become either spirants or voiced stops, depending on their context. ${ }^{18}$

It can now be concluded that Vennemann's diagram in (11) can be greatly simplified:

\footnotetext{
${ }^{18}$ The idea of a single bifurcating push chain representing the laws of Grimm and Verner was first presented by me in Noske (2009). Bynon (1977: 83ff) also presents Grimm's and Verner's laws as a push chain, but because she uses the traditional obstruent system, she fails to solve the paradox noted by Verner himself, i.e. that a direct change from $T$ to $D$ would go against the main direction (as pointed out section 2.4).
} 
(15) The Germanic Sound Shift (my version) ${ }^{19}$
PIE
PG
a. $\mathrm{T} \longrightarrow \mathrm{P}$
b. D $\rightarrow--\rightarrow D$
c. $\mathrm{T} \longrightarrow \mathrm{T}$

In the following section, I will show how this push chain can be formulated in a formal phonological framework.

\section{The Grimm-Verner Chain Shift in Contrast Preservation Theory}

\subsection{Chain shifts and formal phonological theory}

Chain shifts have traditionally been problematic for both input-driven models like SPE and output oriented models like Optimality Theory (OT). In the SPE framework, chain shifts cannot really be accounted for as a unitary phenomenon because they typically involve counter-feeding relationships. For a chain $\mathrm{A}>\mathrm{B}, \mathrm{B}>\mathrm{C}$, a rule changing $\mathrm{B}$ to $\mathrm{C}$ has to apply first, and hence there is no explanation for the shift.

In OT, the problem is the same, if not worse, since here chain shifts involve opaque and non-harmonic changes. ${ }^{20}$ The opacity is incompatible with the idea of a single mapping which depends on a specific constraint ranking, since change tends to go into the direction of an optimum that is determined by that constraint ranking. I.e., it cannot be explained why in a chain $\mathrm{A}>\mathrm{B}, \mathrm{B}>\mathrm{C}$, there is no fusion between original $\mathrm{A}$ and original $\mathrm{B}$, in other words, why $B$ originating from original $A$ does not end up as $C$, just original $\mathrm{B}$ has become $\mathrm{C}$.

Opacity is a notorious problem for OT, and since the introduction of OT, many workarounds have been proposed, such as conjunction, sympathy, multiple strata, dispersion, etc., but none of them have dealt with systemic pressures, which typically result in chain shifts. ${ }^{21}$ A proposal by Łubowicz

${ }^{19}$ This diagram is a simplified. As I mention in section 7.4.4 below, $T$ before $s$ did not spirantize and remained unchanged. A more precise rendering should therefore also contain an arrow between PIE $T$ to PG $T$.

${ }^{20}$ An anonymous reviewer points out that classic OT cannot in fact model chain shifts, while SPE can model them but not explain them.

${ }^{21}$ Kirchner (1996) and Gnanadesikan (1997) have both proposed solutions for opaque chain shifts Kircher introduces a local constraint conjunction, while Gnanasesikan makes a distinction between classical IDENT-type constraints and novel IDENT- 
(2003, to appear) does precisely this. She proposes a theory in which scenarios of changes are compared with one another. In addition, a new type of constraint is introduced, constraints of contrast preservation (PC), which exist alongside markedness constraints. The role of faithfulness constraints is reduced. This theory, termed Contrasts Preservation Theory (or PC Theory), is well-suited to account for chain shifts, as Łubowicz shows for synchronic processes in, among others, Finnish and Polish.

Contrast Preservation Theory differs from other theories on contrast like Dispersion Theory (Flemming 2002) in that it does not focus on (the maximization of) contrast itself, but on phenomena which involve neutralization of contrasts in some contexts and preservation of contrasts in others, as well as on the transparent vs. opaque nature of processes.

Montreuil (2006) has shown that PC Theory can be fruitfully used to provide formal accounts of historical chain shifts. He draws attention to the fact that contrast transformation, which is very frequent in the history of languages, is in fact a chain shift. A well-known example of such a contrast transformation is American English writer [ıаjгə.] vs. rider [ıа:jгə.], where an original voicing contrast has been transformed into a length contrast. ${ }^{22}$

\subsection{Some elements of Contrast Preservation Theory}

Eubowicz proposes three types of PC constraints. ${ }^{23}$ In the description of these types below, $P$ represents a potentially contrastive phonological property, such as a distinctive feature, length, stress, presence vs. absence of a segment.

(16) $\quad \mathrm{PC}_{\mathrm{IN}}(\mathrm{P})$

For each pair of inputs contrasting in $\mathrm{P}$ that map onto the same output in a scenario, assign a violation mark. (Łubowicz 2003: 18)

"If inputs are distinct in P, they need to remain distinct."

(17) $\mathrm{PC}_{\text {out }}(\mathrm{P})$

For each output that corresponds to two or more inputs contrasting in $\mathrm{P}$, assign a violation mark. (Lubowicz 2003: 20)

"Avoid outputs ambiguous in P property."

ADJACENT-type constraints on some scale of similarity. However, the notion of systemic pressure is not accounted for in either analysis.

${ }^{22}$ Using PC theory, Montreuil shows that in Gallo, an originally prosodic contrast was transformed into a segmental one.

${ }^{23}$ For reasons of space, my rendering of Łubowicz's fairly elaborate theory will have to be very limited. 
(18) $\mathrm{PC}_{\mathrm{REL}}(\mathrm{P})$

For a pair of outputs minimally contrasting in $\mathrm{P}$ that does not correspond to a pair of inputs minimally contrasting in $\mathrm{P}$, assign a violation mark. (Lubowicz 2003: 24)

"Avoid transformation of contrast."

The role of $\mathrm{PC}_{\mathrm{REL}}(\mathrm{P})$ is to keep the segments in place and not to allow for random shifts.

\subsection{A formal analysis of the Grimm-Verner Push Chain.}

Let us now look how this type of constraints can be used to work out a formal scenario of the Grimm-Verner chain shift. To begin with, I propose three constraints, one $\mathrm{PC}_{\mathrm{IN}}(\mathrm{P})$ and two $\mathrm{PC}_{\mathrm{REL}}(\mathrm{P})$ constraints:

$$
\begin{aligned}
& \text { (19) } P_{I N}(C G) \\
& \text { (20) a. } P_{\text {REL }} \text { (voice) } \quad \text { b. } P_{\text {REL }} \text { (cont) }
\end{aligned}
$$

$\mathrm{PC}_{\mathrm{IN}}(\mathrm{CG})$ states that a contrast in [constricted glottis] in an input pair (the feature which distinguishes ejective consonants from plain ones) should be present in the output (unless, of course, there are other contrasts between the members of that pair in the output). $\mathrm{PC}_{\mathrm{REL}}$ (voice) says that for a pair of outputs, a minimal contrast in voicing in the output should also be present in the input, and $\mathrm{PC}_{\mathrm{REL}}$ (cont) does the same for the feature [continuant].

I further assumed that $\mathrm{PC}_{\mathrm{IN}}(\mathrm{CG})$ is ranked above $\mathrm{PC}_{\mathrm{REL}}$ (voice) and $\mathrm{PC}_{\mathrm{REL}}$ (cont), which are not ranked with respect to each other:

$$
\text { (21) } \mathrm{PC}_{\mathrm{IN}}(\mathrm{CG})>\left\{\mathrm{PC}_{\mathrm{REL}} \text { (voice), } \mathrm{PC}_{\mathrm{REL}}(\text { cont })\right\}
$$

In Pre-Proto-Germanic, for a hypothetical input pair /at'a/, /ata/ the following evaluation will take place. I distinguish three stages: the initial historical stage (before the advent (or promotion to an undominated position) of a constraint against ejectives), the intermediate historical stage, with the advent of a constraint against ejectives), and a final historical stage. For each example of constraint evaluation that I give, the historical stage is indicated. 
(22) . Initial state: Pre-Proto-Germanic

(identity mapping) at'a, ata $\Rightarrow$ at'a, ata

\begin{tabular}{|l|l|l:l|}
\hline scenario & $\mathrm{PC}_{\mathrm{IN}}(\mathrm{CG})$ & $\mathrm{PC}_{\mathrm{REL}}$ (cont) & $\mathrm{PC}_{\mathrm{REL}}$ (voice) \\
\hline $\begin{array}{l}\text { /at'a } / \rightarrow \text { at'a } \\
\text { /ata/ } \rightarrow \text { ata }\end{array}$ & & & \\
\hline
\end{tabular}

(neutralization of the ejective/plain stop contrast:) at'a, ata $\Rightarrow$ ata, ata

\begin{tabular}{|l|l|l:l|}
\hline scenario & $\mathrm{PC}_{\mathrm{IN}}(\mathrm{CG})$ & $\mathrm{PC}_{\mathrm{REL}}$ (cont) & $\mathrm{PC}_{\mathrm{REL}}$ (voice) \\
\hline $\begin{array}{l}\text { /at'a/ } \rightarrow \text { ata } \\
\text { /ata/ } \rightarrow \text { ata }\end{array}$ & $* !$ & & \\
\hline
\end{tabular}

(contrast transformation) at'a, ata $\Rightarrow$ ata, a $\theta \mathrm{a}$

\begin{tabular}{|l|l|l:l|}
\hline scenario & $\mathrm{PC}_{\mathrm{IN}}(\mathrm{CG})$ & $\mathrm{PC}_{\mathrm{REL}}$ (cont) & $\mathrm{PC}_{\mathrm{REL}}($ voice $)$ \\
\hline $\begin{array}{l}\text { /at'a } / \rightarrow \text { ata } \\
\text { /ata/ } \rightarrow \text { ata }\end{array}$ & & & $*$ \\
& & & $\{$ ata], [ada] $\}$ \\
\hline
\end{tabular}

(contrast transformation) at'a, ata $\Rightarrow$ ata, ada

\begin{tabular}{|l|l|l:l|}
\hline scenario & $\mathrm{PC}_{\mathrm{IN}}(\mathrm{CG})$ & $\mathrm{PC}_{\mathrm{REL}}($ cont $)$ & $\mathrm{PC}_{\mathrm{REL}}$ (voice) \\
\hline /at'a $\rightarrow$ ata & & $*$ & \\
/ata/ $\rightarrow$ ata & & $\{[\mathrm{ata}],[\mathrm{a} \theta \mathrm{a}]\}$ & \\
\hline
\end{tabular}

What we see here is that identity mapping gives the right outcome, because no constraint is violated. I now assume that in the transition from Pre-ProtoGermanic to Proto-Germanic an undominated constraint against ejectives was added (or that this constraint was promoted to an undominated position): *CG (a constraint banning constricted glottis).

(23) . Intermediate historical stage: Proto-Germanic, with introduction (or promotion) of *CG

(identity mapping) at'a, ata $\Rightarrow$ at'a, ata

\begin{tabular}{|l|l|l|l:l|}
\hline scenario & $* \mathrm{CG}$ & $\mathrm{PC}_{\mathrm{IN}}(\mathrm{CG})$ & $\mathrm{PC}_{\mathrm{REL}}$ (cont) & $\mathrm{PC}_{\mathrm{REL}}$ (voice) \\
\hline $\begin{array}{l}\text { /at'a/ } \rightarrow \text { at'a } \\
\text { /ata/ } \rightarrow \text { ata }\end{array}$ & $* !$ & & & \\
\hline
\end{tabular}

(neutralization of the ejective/plain stop contrast:) at'a, ata $\Rightarrow$ ata, ata

\begin{tabular}{|l|l|l|l:l|}
\hline scenario & $* \mathrm{CG}$ & $\mathrm{PC}_{\mathrm{IN}}(\mathrm{CG})$ & $\mathrm{PC}_{\mathrm{REL}}$ (cont) & $\mathrm{PC}_{\mathrm{REL}}$ (voice) \\
\hline /at'a/ $\rightarrow$ ata & & $* !$ & & \\
/ata/ $\rightarrow$ ata & & $\{/$ at'a/,/ata/ $\}$ & & \\
\hline
\end{tabular}

(contrast transformation) at' $\mathrm{a}$, ata $\Rightarrow$ ata, $\mathrm{a} \theta \mathrm{a}$

\begin{tabular}{|l|l|l|l:l|}
\hline scenario & ${ }^{*} \mathrm{CG}$ & $\mathrm{PC}_{\mathrm{IN}}(\mathrm{CG})$ & $\mathrm{PC}_{\mathrm{REL}}$ (cont) & $\mathrm{PC}_{\mathrm{REL}}$ (voice) \\
\hline $\begin{array}{l}\text { /at'a } / \rightarrow \mathrm{ata} \\
\text { /ata } / \rightarrow \mathrm{a} \theta \mathrm{a}\end{array}$ & & & & $*$ \\
& & & & $\{[\mathrm{ata}],[\mathrm{ada}]\}$ \\
\hline
\end{tabular}

(contrast transformation) at'a, ata $\Rightarrow$ ata, ada

\begin{tabular}{|l|l|l|l:l|}
\hline scenario & ${ }^{*} \mathrm{CG}$ & $\mathrm{PC}_{\mathrm{IN}}(\mathrm{CG})$ & $\mathrm{PC}_{\mathrm{REL}}$ (cont) & $\mathrm{PC}_{\mathrm{REL}}$ (voice) \\
\hline$/$ at'a $/ \rightarrow$ ata & & & $*$ & \\
/ata/ $\rightarrow$ ada & & & $\{[$ ata $],[\mathrm{a} \theta \mathrm{a}]\}$ & \\
\hline
\end{tabular}


We now see that the /at'a/, /ata/ pair can now show up either as $\{[\mathrm{ata}]$, [a $\mathrm{a} a]\}$ or $\{[$ ata], [ada]\}. That is, the $t$ in /ata/ either undergoes spirantization (Grimm's Law, act 1 (Germanic Spirantization)) or undergoes voicing (Verner's Law). At this stage of the elaboration of the scenario, there is no way to choose between $a \theta a$ and $a d a$ (both: $<a t a$ ). As shown above in section 2.4, Verner's Law (voicing) applies only after unstressed vowels, while spirantization applies elsewhere. In order to account for the choice of the right process (voicing or spirantization), I introduce here two phonetically grounded constraints, a faithfulness constraint and a markedness constraint:

(24) IDENTPOSTSTRESS (Laryngeal) (IDENTPostSTRLAR).

Consonants directly behind a stressed vowel should be faithful to the underlying laryngeal specification.

This faithfulness constraint is an expression of the view of De Jong, Beckman \& Edwards (1993) that coarticulation effects are reduced in stressed environments, thus impeding intervocalic voicing. ${ }^{24}$ The markedness constraint concerns intervocalic voicing:

\section{(25) INTERVOIVoI}

Consonants should be specified [voiced] if between other segments specified [voiced].

IntervoiVoi is an enlarged version of intervocalic voicing, because it also refers to voiced consonants. ${ }^{25}$ The appropriate ranking of the constraints is IDENTPOSTSTRESSLAR > INTERVOIVOI, while both constraints are ranked below $\mathrm{PC}_{\mathrm{REL}}$ (voice) and $\mathrm{PC}_{\mathrm{REL}}$ (cont). This gives us the following constraint ranking at this point:

(26) $* \mathrm{CG} \mathrm{PC}_{\mathrm{IN}}(\mathrm{CG})>\left\{\mathrm{PC}_{\mathrm{REL}}(\right.$ voice $), \mathrm{PC}_{\mathrm{REL}}($ cont $\left.)\right\}>$ IDENTPOSTSTRESSLAR $>$ INTERVOIVOI

Let us now consider how the selection between spirantization and voicing given above in $(22 b)$ operates:

\footnotetext{
${ }^{24}$ An alternative to IDENTPOSTSTRESSLAR could be a constraint that states that a consonant following a vowel within the same syllable should be faithful to its laryngeal specification. This solution works if one adopts Hoard's (1971) view that a stressed vowel captures a following consonant into its syllable. This view is also adopted by Selkirk (1982) and J.C. Wells (1990). If it is correct, Verner's idea, mentioned in section 2.4 , that intervocalic consonants belong to the former syllable is partially corroborated.

${ }^{25}$ This straightforward widening of Intervocalic voicing is needed because Verner's Law also applied after voiced consonants.
} 
(27) c: Intermediate historical stage: Selection of spirantization and voicing

(contrast transformation) át'a, áta $\Rightarrow$ áta, á $\theta \mathrm{a}$

\begin{tabular}{|r|r|c|l:l|l|l|}
\hline áta & $* \mathrm{CG}$ & $\begin{array}{l}\mathrm{PC}_{\mathrm{IN}} \\
(\mathrm{CG})\end{array}$ & $\mathrm{PC}_{\mathrm{REL}}$ (cont) & $\mathrm{PC}_{\mathrm{REL}}($ voice) & $\begin{array}{l}\text { IDENTPOST- } \\
\text { STRESSLAR }\end{array}$ & $\begin{array}{l}\text { INTERVOI- } \\
\text { VOI }\end{array}$ \\
\hline a á $\theta \mathrm{a}$ & & & $*\{[$ áta], [á $\theta \mathrm{a}]\}$ & & & $*$ \\
\hline áda & & & & $*\{[$ áta], [áda] $\}$ & $* !$ & \\
\hline
\end{tabular}

(contrast transformation) at'á, atá $\Rightarrow$ atá, adá

\begin{tabular}{|c|c|c|c|c|c|c|}
\hline atá & ${ }^{*} \mathrm{CG}$ & $\begin{array}{l}C_{\mathrm{IN}} \\
(\mathrm{CG}) \\
\end{array}$ & $\mathrm{PC}_{\mathrm{REL}}$ (cont) & $\mathrm{PC}_{\mathrm{REL}}$ (voice) & \begin{tabular}{|l} 
IDENTPOST- \\
STRESSLAR
\end{tabular} & $\begin{array}{l}\text { INTERVOI- } \\
\text { VOI }\end{array}$ \\
\hline $\mathrm{a} \theta \mathrm{a}$ & & & $*\{[$ áta], [á $\theta a]\}$ & & & $* !$ \\
\hline 䑩 adá & & & & $*\{[a ́ t a],[a ́ d a]\}$ & & \\
\hline
\end{tabular}

We see that by ranking IDENTPOSTSTRESSLAR above INTERVOIVOI the bifurcation depicted in (14) can be accounted for in the framework of PC Theory.

This concludes my analysis of the Grimm-Verner Push Chain within PC Theory. However, it is necessary to defend it against potential counterexamples. This is the subject of the next section.

\subsection{Residual issues}

\subsubsection{PIE initial voiceless stops}

Initial and final $T$ in Pre-Proto-Germanic always becomes $D$ in ProtoGermanic (and not $D$ ). The above analysis does not account for this. Indeed, in the case of initial or final $T>P$ INTERVOIVOI is not violated; but if $T$ had become $D$, IDENTPOSTSTRESSLAR would also not have been violated. My analysis would thus predict that $D$ and $D$ would both be possible outcomes. The solution to this problem is provided by the following two wellestablished correspondence constraints:

(28) IDENTLAR: Do not change the laryngeal specification of a segment

(29) IDENT-[cont]: do not change the specification of [cont] of a segment

Now the following constraint ranking can be established:

(30) * $\mathrm{CG} \mathrm{PC}_{\mathrm{IN}}(\mathrm{CG})>\left\{\mathrm{PC}_{\mathrm{REL}}(\right.$ voice $), \mathrm{PC}_{\mathrm{REL}}($ cont $\left.)\right\}>$ IDENTPOSTSTRESSLAR $>$ INTERVOIVOI $>$ IDENTLAR $>$ IDENT-[cont]

The following evaluation can now be established for initial $T$ : 
(31) Intermediate historical stage: initial PIE T

\begin{tabular}{|c|c|c|c|c|c|c|c|c|}
\hline \multirow[t]{2}{*}{$/ \mathrm{t}^{\prime} \mathrm{a} /, / \mathrm{ta} /$} & \multirow[t]{2}{*}{$* \mathrm{CG}$} & \multirow{2}{*}{$\begin{array}{l}\mathrm{PC}_{\mathrm{IN}} \\
(\mathrm{CG})\end{array}$} & \multicolumn{2}{|c|}{$\mathrm{PC}_{\mathrm{REL}}$} & \multirow{2}{*}{\begin{tabular}{|l} 
IDENTPOST- \\
STRESSLAR
\end{tabular}} & \multirow{2}{*}{\begin{tabular}{|l|} 
INTER- \\
VOIVOI
\end{tabular}} & \multirow{2}{*}{\begin{tabular}{|l|} 
IDENT \\
-LAR \\
\end{tabular}} & \multirow{2}{*}{\begin{tabular}{|l|} 
IDENT \\
(CONT)
\end{tabular}} \\
\hline & & & (cnt) & (vce) & & & & \\
\hline t'a, ta & $* !$ & & & & & & & \\
\hline ta, ta & & *! & & & & & & \\
\hline ta, da & & & & * & & & $* * !$ & \\
\hline 吗 ta, $\theta \mathrm{a}$ & & & * & & & & * & * \\
\hline
\end{tabular}

7.4.2 PIE final voiceless stops.

Another problem concerns the PIE final voiceless stops. According to the traditional version of Verner's Law, $T$ turns into $D$ when preceded by an unstressed vowel. However, the constraint IntervoiVoi (cf. (25)), combined with constraint ranking as given in (30), produces $P$ whenever PIE $T$ is in final position. This counterexample is not valid if one adopts Mańczak's (1990) stance that Verner's Law did not apply word-finally. Mańcak mentions no less than five arguments which show that the evidence for a word-final application of Verner's voicing is very scant or non-existent. This confirms a dictum by an early researcher on Verner's Law: "[a]nd if once the true nature of Verner's Law be sufficiently understood, it will be obvious that its conditions are exactly those most favorable to intervocalic voicing." (F.L. Wells 1903-1905: 526).

\subsubsection{Possible fusion of $T$ and $D$}

Our third problem concerns the fact that in our model of the Grimm-Verner Push Chain, one does indeed find an instance of non-preservation of contrast. As one can see in the diagram in (15), $D$ can have an ambiguous input: it is either $D$ or $T$. It suffices to realize that here there is no highly ranked $\mathrm{PC}_{\mathrm{IN}}$ constraint for the feature [voice] (or, rather, that the $\mathrm{PC}_{\mathrm{IN}}$ (voice) constraint is low in the constraint hierarchy), and hence $T$ can turn into $D$ when IntervoiVoi blocks other outputs.

\subsubsection{T does not spirantize before $s$ or as second member of a stop cluster}

A fourth apparent counter-example concerns the fact that, as is well known, PIE $T$ did not spirantize in PG if it was preceded by $s$, or if it was the second member of a cluster of two plain voiceless stops (the first member of which did spirantize, like in Germ. Haft vs. Lat. capt-). A straightforward explanation for this is a tendency in the form of a non-dominated OCP constraint $^{26}$ that excludes a sequence of two obstruents sharing the same

\footnotetext{
${ }^{26}$ The generally accepted Obligatory Contour Principle (OCP), proposed by
} McCarthy $(1986,1988)$, states that on the melodic level, identical elements are 
feature specification for [continuant]. Such a constraint is needed for many languages as dissimulation processes regarding [continuant] abound across languages. ${ }^{27}$

\subsection{The final historical stage}

In the final historical stage, the processes were lost and the results were lexicalized. The underlying form containing $T$ ' in PIE contained $T$ in this stage and those containing $T$ in PIE now contained $D$ or $D$ (or still $T$ for the cases mentioned in section 7.4.4). Hence there was now a new obstruent inventory:

\section{(32) The new PG obstruent inventory $\mathrm{T}(<\mathrm{T}, \mathrm{T}), \mathrm{P}(<\mathrm{T}), \mathrm{D}(<\mathrm{T}, \mathrm{D}), s$}

Later, there was additional intervocalic voicing. This has become possible because $\mathrm{PC}_{\mathrm{REL}}$ (cont) and $\mathrm{PR}_{\mathrm{REL}}$ (cont) did not play a role anymore: they refer to contrast transformation $\left(t^{\prime} / t \Rightarrow t / \theta\right.$ and $\left.t^{\prime} / t \Rightarrow t / d\right)$, but the $t^{\prime}$ is no longer there. Therefore, we find $z$ and $\partial$ in later texts.

Finally, the conditioning factor of stress was destroyed, because of the stress shift to the initial position (see section 2.2).

\section{Conclusions}

In this paper, I have given a new interpretation of the history of the ProtoGermanic obstruent system. I have shown that Grimm's and Verner's laws can be analyzed as two subprocesses of a single system-driven process that was essentially a bifurcating sound shift under the influence of the pushing power of Deglottalization (which replaces act 3 of Grimm's Law). This

prohibited. Here, the OCP would apply to the melodic level where the feature [continuant] is located.

${ }^{27}$ Examples of this type of dissimilation can be found in, e.g., Modern Greek, where this type of manner dissimilation is quite common, e.g. in $\varphi \tau \eta v o ́ \varsigma$ 'cheap', which is pronounced as [ffinos] in the learned (Katherevousa) variety of the language but as [ftinos] in the colloquial (Demotiki) variety, and in $\lambda \varepsilon \pi \tau \dot{\alpha}$ 'minutes', which is pronounced as [lepta] in the learned variety but as [lefta] in the colloquial variety (Newton 1972: 88). Cf. also the English form fifth [fife], which is pronounced as [fift] in certain dialects, although $\theta$ shows up in other positions in these dialects. 
pushing power resulted from the need to maintain contrastivity between original ejectives and original plain voiceless stops. In order to do this, the Glottalic Theory was adopted, which enabled a change $\mathrm{T}>\mathrm{D}$ without going 'against the main direction of the sound change'.

The major upshot of the above analysis is that Deglottalization, Germanic Spirantization (formerly act 1 of Grimm's Law) and Verner's Law are now related and therefore necessarily synchronous with each other. One does not, therefore, have to answer the question whether Grimm's Law preceded or followed Verner's Law. Neither does one have to wonder why in the transition from PIE to PG there were two processes that applied to the same original segments, i.e. the plain voiceless stops.

The second part of the paper presented a formal phonological analysis of this chain shift within Contrast Preservation Theory, building on work by Łubowicz (2003, to appear). Like the analysis presented in Montreuil (2006), this analysis shows that historical chain shifts can find their formal expression in modern phonological theory.

\section{References}

Baldi, Philip \& Ronald N. Werth (eds.) (1970): Readings in Historical Phonology: Chapters in the Theory of Sound Change. - University Park, Penn.: Pennsylvania State University Press.

Blust, Robert (1974: 'A double counter-universal in Kelabit.' - In: Papers in Linguistics 7, 309-324.

- (2006): 'The Origin of the Kelabit Voiced Aspirates: A Historical Hypothesis Revisited.' - In: Oceanic Linguistics 45.2, 311-338.

Brugmann, Karl \& Berthold Dellbrück (1886): Grundriss der vergleichenden Grammatik der indogermanischen Sprachen. Erster Band: Einleitung und Lautlehre. Strassburg: Trübner. Second revised edition published in 1897.

Bynon, Theodora (1977): Historical Linguistics. - Cambridge: Cambridge University Press.

Campbell, Alistair (1959): Old English Grammar. - Oxford: Claredon Press.

Campbell, Lyle (2004): Historical Linguistics: an Introduction (2nd edition). Edinburgh: Edinburgh University Press, and Cambridge, MA: MIT Press. [First edition published in 1994].

Chomsky, Noam \& Morris Halle (1968): Sound Pattern of English. - New York: Harper \& Row.

De Jong, Kenneth, Mary E. Beckman \& Jan Edwards (1993): “The Interplay between Prosodic Structure and Coarticulation”. - In: Language and Speech 36, 197-212.

Emonds, Joseph (1972): "A reformulation of Grimm's Law". - In: Brame, Michael (ed.), Contributions to Generative Phonology, 108-122. Austin: University of 
Texas Press,

Flemming, Edward S. (2002): Auditory representations in phonology. - New York: Routledge.

Fox, Anthony (1976): "Problems with phonological chains." - In: Journal of Linguistics 12, 289-310.

Gamkrelidze, Thomas V. \& Vjačeslav V. Ivanov (1973): "Sprachtypologie und die Rekonstruktion der gemeinindogermanischen Verschlüsse”. - In: Phonetica 27, 150-156.

- (1995): Indo-European and the Indo-Europeans. - Berlin: Mouton de Gruyter.

Gnanadesikan, Amalia E. 1997. Phonology with Ternary Scales. - Ph.D. dissertation, University of Massachusetts, Amherst.

Grimm, Jacob (1822): Deutsche Grammatik. vol. I. 2nd ed. - Göttingen: Dieterich.

- (1848): Geschichte der deutschen Sprache. - Leipzig: In der Weidmannschen Buchhandlung.

Haider, Hubert (1985): "The fallacy of typology. Remarks on the PIE stop-system." - In: Lingua 65, 1-27.

Haudricourt, André-Georges (1975): "Les mutations consonantiques (occlusives) en indo-européen”. - In: Bader, Françoise et al. (eds.): Mélanges offerts à Emile Benveniste, 267-272. Paris: Société linguistique de Paris.

Hoard, James. E. (1971): “Aspiration, Tenseness and Syllabification in English". - In : Language 47, 133-140.

Hogg, Richard M. (1992): A Grammar of Old English. Vol. 1 Phonology. - Oxford: Blackwell.

Hopper, Paul J. (1973): "Glottalized and Murmured Occlusives in Indo-European". - Glossa 7, 141-166.

- (1977a): "Indo-European consonantism and the "new look". - Orbis 26, 57-72.

- (1977b): "The typology of the Proto-Indo-European segmental inventory". - In: Journal of Indo-European Studies 5, 41-53.

- (1982): "Areal typology and the Early Indo-European consonant system" - In: Edgar C. Polome' (ed.): The Indo-Europeans in the fourth and fifth millennia, 121139. Ann Arbor: Karoma.

Jakobson, Roman. (1958): "Typological Studies and their Contribution to Historical Linguistics." - In: Proceedings of the 8th International Congress of Linguists (Oslo 1957), 17-35. Also published in: Jakobson, Roman (1971): Selected Works, vol. I: Phonological Studies, 523-532. - The Hague: Mouton.

Jespersen, Otto (1933): "Verners gesetz und das wesen des akzents". - In: Linguistica: selected papers in English, French and German, 228-248. København: Levin $\&$ Munksgaard,

Job, D. Michael (1995): "Did Proto-European have Glottalized Stops?" - In: Diachronica 12, 237-250.

Kirchner, Robert (1996): "Synchronic Chain Shifts in Optimality Theory". - In: Linguistic Inquiry 27, 341-350.

Kiparsky, Paul (1971): Phonological Change. - Bloomington: Indiana University Linguistics Club [originally $\mathrm{PhD}$ dissertation MIT, 1965].

(1973): “"Elsewhere' in Phonology". - In: Anderson, Stephen \& Paul Kiparsky (eds.): A Festschrift for Morris Halle, 93-106. New York, London [etc.]: Holt, 
Rinehart and Winston.

- (1982): "Lexical Phonology and Morphology". - In: Linguistics in the Morning Calm, 3-91. Edited by The Linguistics Society of Korea. Seoul: Hanshin Publishing Co.

Kortlandt, Frederik (1985): "Proto-Indo-European Glottalic Stops: the Comparative Evidence". - In: Folia Linguistica Historica 6, 183-201.

- (1988): "Proto-Germanic Obstruents". - In: Amsterdamer Beiträge zur älteren Germanistik 27, 3-10.

Koutsoudas, Andreas, Gerald Sanders \& Graig Noll (1974): "The application of phonological rules". - In: Language 50, 1-28. (Drafted 1971).

Kretschmer, Paul (1932): "Die Urgeschichte der Germanen und die germanische Lautverschiebung." - In: Wiener prähistorische Zeitschrift 19, 269-280.

Kümmel, Martin-Joachim. 2007. Konsonantenwandel. - Wiesbaden: Reichert Verlag.

- (2012): "Typology and Reconstruction: The consonants and vowels of ProtoIndo-European." - In: Benedicte Nielsen Whitehead, Thomas Olander, Birgit Anette Olsen \& Jens Elmegård (eds): The Sound of Indo-European, Phonemics and Morphophonemics (Copenhagen Studies in Indo-European 4), 291-312. Copenhagen: Museum Tusculanum

Lehmann Winfred P. (1952): Proto-Indo-European Phonology. - Austin: University of Texas Press and Linguistic Society of America. Available online at: http://www.utexas.edu/cola/centers/lrc/books/piep00.html.

- (1961): "A Definition of Proto-Germanic: A Study in the Chronological Delimitation of Languages." - In: Language 37, 67-74.

- (1967): A reader in nineteenth-century historical Indo-European linguistics. Ed. and transl. by Winfred P. Lehmann. - Bloomington, Indiana: Indiana University Press. Available online at: http://www.utexas.edu/cola/centers/lrc/books/readT.html.

Lottner, Carl (1862): "Ausnahmen der ersten Lautverschiebung." - In: Zeitschrift für vergleichende Sprachforschung auf dem Gebiete des Deutschen, Griechischen und Lateinischen 11.3, 161-205. English translation in Lehmann (1967).

Łubowicz, Anna. (2003): Contrast Preservation in Phonological Mappings. Ph.D. dissertation, University of Massachusetts, Amherst. - Amherst, Mass.: GSLA. ROA-554.

- (to appear): The Phonology of Contrast. - London: Equinox.

Luick, Karl (1940): Historische Grammatik der englischen Sprache. Bd. 1, Abt. 1-2. - Leipzig: Bernhard Tauchnitz.

McCarthy, John J. (1986): "OCP Effects: Gemination and Antigemination”. - In: Linguistic Inquiry 17, 207-263.

- (1988): "Feature Geometry and Dependency: a review." - In: Phonetica 45, 84108.

Mańczak, Witold (1990): "La restriction de la règle de Verner à la position médiane et le sort du $s$ final en germanique". - In: Historische Sprachforschung 103, 92-101.

Martinet, André (1955): Economie des changements phonétiques. Traité de phonologie diachronique. - Bern: Francke.

Montreuil, Jean-Pierre (2006): "Contrast Preservation Theory and Historical Change". - In: Gess, Randall S. \& Deborah Arteaga (eds.), Historical Romance Linguistics. 
Retrospective and Perspectives, 111-129. Amsterdam/Philadelphia: Benjamins.

Newton, Brian (1972): The Generative Interpretation of Dialect: a study of modern Greek phonology. - Cambridge: Cambridge University Press.

Noske, Roland (2009): "Verner's law, phonetic substance and form of historical phonological description". - In: Proceedings JEL'2009 (dis)continu, 6th Nantes Linguistic Meeting, 33-42

Pedersen, Holger (1951): Die gemeinindoeuropaischen und die vorindoeuropaischen Verschlußlaute. - København: Munksgaard. Det kongelige Danske Videnskabernes Selskab 32(5).

Pullum, Geoffrey K. (1976): “The Duke of York gambit”. - In: Journal of Linguistics $12,83-102$.

Rask, Rasmus (1818): Undersögelse om det gamle Nordiske eller Islandske Sprogs Oprindelse: et af det Kongelike Danske Videnskabers Selskab kronet Prisskrift. Kjøbenhavn: Gyldendalske Boghandlings Forlag. Republished in 1999 by Routledge, London. English translation published in 1993 as: Investigation of the Origin of the Old Norse or Icelandic language. - Copenhagen: The Linguistic Circle of Copenhagen. German translation published in 1932, in: Rask, Rasmus, Ausgewählte Abhandlungen, vol. 1, ed. by Louis Hjelmslev. Kopenhagen: Levin \& Munksgaard.

Salmons, Joseph C. (1993): The Glottalic Theory. Survey and Synthesis. - McLean, Virginia: Institute for the Study of Man.

Selkirk, Elisabeth O. (1982): "The Syllable". - In: Van der Hulst, Harry \& Norval Smith eds., The Structure of Phonological Representations, vol. II, 337-383. Dordrecht: Foris.

Vennemann, Theo (1984): "Hochgermanisch und Niedergermanisch". - In: Beiträge zur Geschichte zur deutschen Sprache und Literatur (Tübingen) 106, 1-45.

Vennemann, Theo (1985): "The bifurcation theory of the Germanic and German consonant shifts synopsis and some further thoughts". - In: Fisiak, Jacek (ed.): Papers from the 6th International Conference on Historical Linguistics, 527-547. Amsterdam: Benjamins,

- (2006): "Grimm's Law and Loanwords". - In: Transactions of the Philological Society 104.2, 129-166.

- (ed.), (1989): The New Sound of Indo-European: Essays in Phonological Reconstruction. Proceedings of a Workshop held during the Seventeenth International conferend on Historical Linguistics held on Sept 9-13 1985 at the University of Pavia. - Berlin: Mouton de Gruyter.

Verner, Karl (1876): "Eine ausnahme der ersten lautverschiebung". - In: Zeitschrift für vergleichende Sprachforschung auf dem Gebiete der indogermanischen Sprachen 23, 97-130. English translations in Baldi \& Werth (1978:32-63) and Lehmann (1967).

Wells, Frederic L. (1903-1905): "Experimental Phonetics and Verner's Law". - In: Journal of English and Germanic Philology 5, 522-527.

Wells, John C. (1990): "Syllabification and Allophony." - In: Susan Ramsaran (ed.): Studies in the pronunciation of English, a commemorative volume in honour of A.C. Gimson. 76-86. London and New York: Routledge. Downloadable from: http://www.phon.ucl.ac.uk/home/wells. 